AGRO EKONOMI, Vol 32, Issue 1, June 2021, Page.40-51

DOI : http://doi.org/10.22146/ae.61429

ISSN 0215-8787 (print), ISSN 2541-1616 (online)

Available at https://jurnal.ugm.ac.id/jae/

\title{
Factor Analysis on Rice Product Labels as a Consideration for Consumer's Purchase Decision In Yogyakarta
}

\author{
Melani Yulinar Khasanah ${ }^{1}$, Jamhari ${ }^{2}$, Dwidjono Hadi Darwanto ${ }^{3}$ \\ ${ }^{1}$ Mahasiswa Program Pascasarjana Manajemen Agribisnis, Fakultas Pertanian, \\ Universitas Gadjah Mada \\ 2,3 Departemen Sosial Ekonomi Pertanian, Fakultas Pertanian, \\ Universitas Gadjah Mada \\ Jalan Flora, Bulaksumur, Depok, Sleman, Daerah Istimewa Yogyakarta
}

Submitted : 19 November 2020 ; Revised : 3 March 2021 ; Accepted : 31 May 2021

\begin{abstract}
Rice is one of the staple foods consumed by most Indonesians. As a widely consumed product, rice production labeling is highly concerned with the latest health issues. Labels are expected to provide useful information in determining products to be purchased by consumers, so it is necessary to attain the information of consumers' expectations. This study aims to determine the attributes on the label from consumers' consideration when making purchasing decisions. This research was conducted in May - August 2020. The online questionnaire was filled in by 125 respondents who purchased rice products in the last one month in Yogyakarta City and Sleman Regency, considering the current conditions (the Covid-19 pandemic). Determination of the factors taken into consideration using the Confirmatory Factor Analyze (CFA) method and appropriate statistical tools were used to analyze the data. The results showed that 74\% of the respondents purchased labeled rice products in the last month. As many as $98.65 \%$ of respondents who bought labeled rice read the labels before making a purchase decision, and $78.38 \%$ considered labeling rice products important. Two factors considered when making a purchasing decision were product specifications which consist of price and production code; also, product quality consists of organic labeling, net weight, nutritional content, BPOM registration number, and SNI label.
\end{abstract}

Keywords : CFA, Product Quality, Product Specification.'

How to cite : Khasanah, M.Y., Jamhari, and Darwanto, D.H. 2021. Factor Analysis on Rice Product Labels as a Consideration for Consumer's Purchase Decision in Yogyakarta. Agro Ekonomi 32(1), 40-51

\section{INTRODUCTION}

Rice is one of the staple foods consumed by most Indonesians. Indonesia's rice consumption from 2011 to 2017 has increased from $27,337,358$ tons to 29,133,513 tons (Badan Pusat Statistik, 2019). This condition is due to the rice categorized as staple food whose availability is always expected to meet needs.

Consumers consider various factors before buying a product. Food generally contains a variety of nutrients that are indispensable for optimal 
body function, and it is stated that the consumer decisions before buying or consuming any food product are a function of food quality, price, packaging, and labels (Daud et al., 2011)

Considerations before purchasing can be observed physically as well as sensory. This sensory form can be seen in the form of a label. According to (Abigail et al., 2012), food labeling is an essential communication tool between consumers and food producers. Labels provide information that consumers expect to be useful in determining decisions about products to buy. In rice products, labeling is carried out by producers to display the information they want to convey to consumers, while consumers use labeling as a mean to obtain information and to adjust the criteria for the product they are going to buy. Serving as an extrinsic cue, labels in food products allow consumers to evaluate products so that they can make well-informed choices (Lagerkvist, 2013). The primary purpose of labeling is to deliver information from producers to consumers (Van Boxstael et al., 2014). In general, label content's effectiveness is related to having trust information for consumers (Liao et al., 2015), resulting in an emotional relationship in purchasing decision-making (Escandon-Barbosa \& Rialp-Criado, 2019).

According to Kotler (2002), a label is a simple display of an intricately designed product or image integral part of the packaging. In Indonesia, the regulation regarding food labels is regulated by UU No. 7 Tahun 1996, which states that foreveryone who produces or imports food packaged for trade, it is obligatory to state the label on, inside, and or on the food packaging, which at least contains: name of the product, list of ingredients used, net weight or net content, name, and address of the party producing or importing food into the territory of Indonesia, information regarding halal, date, month, and year of expiration.

Labels on food products are necessary because they convey information intended by producers to consumers through information written on labels (Kumar \& Kapoor, 2017). This information is required by consumers to choose the product that best matches their expectations because they have the right to know about the product profile (Vecchio \& Annunziata, 2012). These consumers' various kinds of information show consumer attention to label food products since most consumers often read the information on the labels. According to Campos et al. (2011), worldwide consumers are aware of the importance of food labels which are in line with consumers' increasing concern due to the food crisis, the emergence of diseases due to unregulated diets, and 
poor food quality. Some information on labels that consumers find most useful includes price, health warnings, production codes, nutrient quantities, and storage methods. The level of importance of the label information can be grouped as product quality and product specifications (Kumar \& Kapoor, 2017).

This study aims to determine the label's attributes taken into consideration when making rice product purchasing decisions. Research on rice product labeling is still rarely carried out, so it needs to be paid attention again, considering that rice is the staple food of Indonesia. This study results can be used by producers and policymakers to deliver adequate information to consumers through labels on these rice products.

\section{METHODS}

The primary method used in this research was descriptive analysis. The research was conducted in Yogyakarta City and Sleman Regency, Yogyakarta Special Region on May - August 2020. Samples were taken by accidental sampling because they accidentally appeared and filled out the questionnaire. The total number of respondents was 125 , who were also purchased rice in the last one month. In the conditions of the Covid-19 pandemic like this, sampling was carried out online using the google form. Samples were distributed online using various types of social media, as well as in person. The data used in this research were primary and secondary data. Secondary data was obtained from the literature study and previous research.

\section{Validity Test}

The validity test was used to measure whether a questionnaire is valid or not by looking at the calculated $r$-value The test results are interpreted if $r$ value $>r$ table, then the item being tested is valid, whereas if $r$ value $\leq r$ table, then the item being tested is invalid.

\section{Reliability Test}

Reliability shows reliability and consistency in research. The questionnaire is reliable if someone's answer to a question or statement is consistent or stable over time. Reliability testing in this study used Cronbach's Alpha. The test was processed with the SPSS program. A variable is said to be reliable if it has a Cronbach's Alpha value $\geq$ of 0.60 .

\section{Factor Analysis}

The label attribute on rice products that consumers consider essential consisted of price (X1), rice product 
trademark (X2), production code (production date and expiration date) (X3), rice product producers (X4), rice varieties (X5), organic label (X6), net weight (X7), nutritional content (X8), BPOM registration number (X9), SNI label (X10). For all these attributes, an assessment was carried out using a Likert scale using a score of 5 points-a score of 1 for not very important to 5 for very important.

Identifying two main categories of factors into product quality and product specifications explains the increased awareness and concern of consumers related to the processes and conditions in which these products are grown, processed, and marketed. Simplifying the label attributes into two factors aims to see which attributes indicate product specifications in the rice label and product quality. The analysis used to answer these objectives was factor analysis.

The main objective in factor analysis is to summarize the original variables' information into a new set of dimensions or factors. This study will use CFA as the analysis tool. In Confirmatory Factor Analysis (CFA), the number of factors formed was the analysis factor because the group of variables analyzed should be related to one another because the analysis factor investigates the underlying similarities between the variables. The variable used was the consumer's interest in each of the detailed label attributes, which will then produce a model:

$$
\mathrm{X}_{\mathrm{p}}-\mu_{\mathrm{p}}=\Lambda_{\mathrm{p} 1} \mathrm{~F}_{1}+\ldots .+\Lambda_{\mathrm{pq}} \mathrm{F}_{\mathrm{q}}+\varepsilon_{\mathrm{q}}
$$

Where,

$\mathrm{X}$ : variable vector

$\mu_{\mathrm{i}}$ : the average of the $\mathrm{i}$-th variable

$\Lambda_{\mathrm{i}}$ : loading for the $\mathrm{i}$-th variable in the j-th factor

$F_{j}$ : common factors

$\varepsilon_{\mathrm{i}}$ : specific factors (specific factors) i-th variable

$i=1,2, \ldots, p$ and $j=1,2, \ldots, q$

Several tests carried out when conducting factor analysis were:

a. Barlett's Test of Sphericity is used to test that the variables in the sample are correlated.

The KaiserMeyer Olkin (KMO) test is used to determine sample adequacy or measure sample eligibility. Overall KMO values $\geq .70$ are desired (Lloret et al., 2017).

b. The Measure of Sampling Adequacy (MSA) test is used to measure degrees correlation between variables with MSA criteria greater than 0.5

\section{RESULTS AND DISCUSSION}

Labels listed on food products in this study are rice containing various 
kinds of different information adjusted by the manufacturer. The label attribute in this study was based on several government regulations and laws combined with previous research. In the future, the results of this analysis can be used by manufacturers in making better label planning.

\section{Validity and Reliability Test}

Validity testing used SPSS v.20 software with the method used by Pearson Product Moment. This method was used to see the relationship between each question item's score with the total score of all these questions. The basis for the decision used in testing this validity is to look at the calculated r-value compared to the r-table. If $r$ count $>r$ table, then the item being tested is valid. The value of $r$-count on each question item was greater than the $r$ table with a value of 0.165 under confidence level of $95 \%$ ( $\alpha 5 \%$ ), which means that the items in the questionnaire used are valid and can be used in research.

Reliability testing of the question items were required as well. It used the same software using Cronbach's Alpha indicator. If the value of Cronbach's Alpha is higher than 0.60 , it is stated that the item is reliable. The value of Cronbach's alpha after testing is 0.790 , which is greater than 0.60 , so that the items on the question are consistent.

\section{Information for Consumers on Rice} Product Labels

Consumers' awareness of reading the information on different labels can be affected by several conditions. Some consumers prefer to read the label first if they are about to buy the rice product for the first time; subsequent purchases will only adjust to the previous one.

There were 74 out of 125 respondents purchasing labeled rice products in the last one month. Most consumers buying rice products often read the labels on rice products before buying the product. Details of consumers reading rice product labels can be seen in table 1.

The information on the label is used for communication between producers and consumers. Consumers often check what information is on the label before deciding to buy or not buy the product. In some cases of first-time product purchases, the label's information plays an important role (Aygen, 2012). Some consumers change their minds after reading the label's information and then decide not to buy the product (Wade \& Kennedy, 2010). The majority of respondents in their research tended to check labels when making purchasing decisions because they evaluate the suitability of food products for vegetarians, religious reasons, to avoid food-related diseases, 
Table 1. Label Reading Before Purchasing

\begin{tabular}{lrr}
\hline $\begin{array}{l}\text { Do you read the information on } \\
\text { the label before purchase? }\end{array}$ & Number (Inhabitants) & $\begin{array}{c}\text { Percent } \\
\text { (\%) }\end{array}$ \\
\hline Never & 1 & 1.35 \\
Rarely & 11 & 14.86 \\
Sometimes & 16 & 21.62 \\
Often & 21 & 28.38 \\
Always & 25 & 33.78 \\
\hline Total & 74 & 100.00 \\
\hline
\end{tabular}

Tabel 2. The Importance of Labels For Consumers

\begin{tabular}{lrc}
\hline Importance of Food Labelling & Number (Inhabitants) & Percent (\%) \\
\hline Very not important & 2 & 2.70 \\
Not important & 14 & 18.92 \\
Quite important & 17 & 22.97 \\
Important & 26 & 35.14 \\
Very important & 15 & 20.27 \\
\hline Total & 74 & 100.00 \\
\hline
\end{tabular}

and to check whether these foods are grown organically or not (Bandara et al., 2016). Most of the respondents who bought labeled rice products (55.41\%) thought that the label on rice products is an important and essential thing before making a purchase decision. Information on the label can be taken into consideration related to the rice product to be purchased.

The average score given by respondents with a value range between 1 and 5 can be seen in table 3. The results show that the price attribute had the highest value, which means that consumers consider a price tag on rice products as necessary. Price remains the most crucial information customers always look for before they buy a product. Price has become one of the main factors determining the final purchase of food products (Singla, 2010). Apart from price, production code and net weight have a mean value above four, which means their existence is also considered essential. The production code, along with the expiration date and storage instructions, reflects two characteristics: their preference for fresh produce and their intention to store it for future use (Kumar \& Kapoor, 2017). Information on nutritional value has a mean score below the BPOM and SNI labeling. Consumers appreciate the existence of health information on food packaging; even though they do not need it, they 
are only more likely to be convinced that the information is included (Hodgkins et al., 2012). The producer attribute of rice products has the lowest average value among the attributes in the study. Details of attributes on rice product labels can be seen in table 3 .

\section{Factor Analysis}

Attributes on labels were grouped to determine which attributes are considered when making purchasing decisions analyzed using SPSS v.20 with a factor analysis method. The type of factor analysis used was Confirmatory Factor Analysis. According to Prudon (2015), Confirmatory Factor Analysis is useful for testing how measurable variables are good at describing or representing a number in factors called a construct in the CFA. This study refers to research conducted by (Kumar \& Kapoor, 2017), which divided the factors into two factors, namely product specifications, and product quality. Identifying two main categories of factors into product quality and product specifications explained the increased awareness and concern of consumers related to the processes and conditions in which these products were grown, processed, and marketed.

Barlett's Test of Sphericity was used to determine whether there was a correlation between the samples. In table 4 , the significance value of Bartlett's Test
Table 3. Attributes on Rice Product Labels

\begin{tabular}{lc}
\hline Attributes & $\begin{array}{l}\text { Average } \\
\text { score }\end{array}$ \\
\hline Price & 4.23 \\
Product Brand & 3.58 \\
Production Code & 4.17 \\
Varieties & 3.97 \\
Organic Labelling & 3.63 \\
Producer & 3.58 \\
Net weight & 4.18 \\
Nutritional Information Label & 3.85 \\
BPOM Registration Number & 3.96 \\
SNI Label & 3.94 \\
\hline ** 1 : not very important ; $5:$ very \\
important
\end{tabular}

Table 4. Barlett's Test of Spericity and KaiserMeyer Olkin Measure of Sampling Adequency Test (KMO-MSA)

\begin{tabular}{llr}
\hline $\begin{array}{l}\text { Kaiser-Meyer-Olkin Measure } \\
\text { of Sampling Adequacy. }\end{array}$ & 0.737 \\
\hline $\begin{array}{l}\text { Bartlett's } \\
\text { Test of }\end{array}$ & Approx. Chi- & 206.516 \\
Sphericity & Dfuare & 21 \\
& Sig. & 0.000 \\
\hline
\end{tabular}

of Sphericity is 0.00 smaller than $\alpha 5 \%$, which means it meets the requirements for factor analysis to be carried out.

The Kaiser Meyer Olkin Measure of Sampling Adequacy (KMO-MSA) test was used to test the sample's feasibility for factor analysis. The basis for decision making is by looking at the KMO-MSA value $>0.5$. The KMO-MSA value was $0.737(>0.5)$, so that the sample to be used in the factor analysis met both testings' requirements. Details of the test results can be seen in table 4 . 
The next analysis was to analyze each variable to determine which variable was suitable for further analysis, which had an MSA value> 0.5. This value can be seen in the Anti-image Correlation table. If the MSA value is less than 0.5 , the variable must be excluded, and then another step is done without including the variable. In this study, all variables had an MSA value larger than 0.5 , which means that all variables could be included in the analysis.

Components or factors with an initial eigenvalue larger than one were maintained and became factors formed. Furthermore, factors having an initial eigenvalue $<1$ was not be included in the model. Apart from looking at the Total Variance Explained, determining the number of factors can also be seen based on the scree plot in Figure 1.

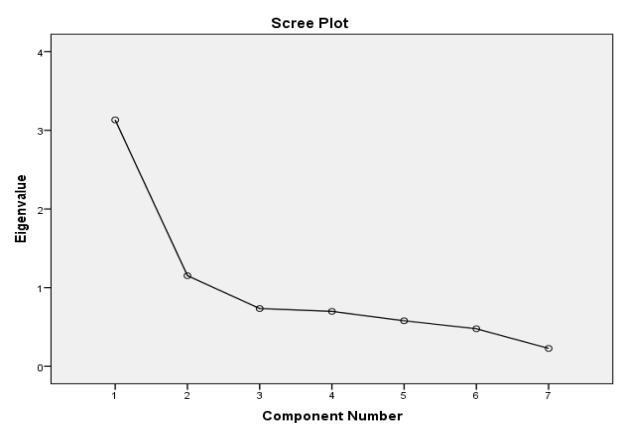

Figure 1. Scree plot

After it was known that the two most optimal factors had been formed, the rotated component matrix table shows the distribution to the variable's front. In contrast, the numbers in the table are factor loading, showing the magnitude of the correlation between a variable with factor 1 and factor 2 , which later were used to determine the position of these variables. The greater the factor loading value in the rotated component matrix table, the greater the variable's significance was included in one of the factors.

The factor analysis used in this study was the Confirmatory Factor Analysis, which refers to previous research. In this study, two factors from seven variables were formed: product specifications and product quality, as shown in Table 6. Factor 1 product specification consisted of rice products' price and production code, while factor 2 product quality consisted of giving organic certification labels, net weight, nutritional content, BPOM registration number, and SNI label. The new factors were named according to the relationship between the variables incorporated into each new factor. This research refers to a similar analysis conducted by Kumar \& Kapoor (2017), examining the labeling of food products, resulting in two factors formed, namely product specifications and product quality, which were also involved in this study. Details of the results of the factor analysis can be seen in table 5 and can be written in this following equation : 

a. $\mathrm{X} 1=\mathrm{L}_{\mathrm{x} 1}$ Product Specification $+\mathrm{e}_{3}$
b. $\mathrm{X} 3=\mathrm{L}_{\mathrm{x} 3}$ Product Specification $+\mathrm{e}_{3}$
c. $\mathrm{X} 5=\mathrm{L}_{\mathrm{x} 5}$ Product Quality $+\mathrm{e}_{5}$
d. $\mathrm{X} 6=\mathrm{L}_{\mathrm{x} 6}$ Product Quality $+\mathrm{e}_{6}$
e. $\mathrm{X} 7=\mathrm{L}_{\mathrm{x} 7}$ Product Quality $+\mathrm{e}_{7}$
f. $\quad \mathrm{X} 8=\mathrm{L}_{\mathrm{x} 8}$ Product Quality $+\mathrm{e}_{8}$
g. $\mathrm{X} 9=\mathrm{L}_{\mathrm{x} 6}$ Product Quality $+\mathrm{e}_{9}$
h. $\mathrm{X} 10=\mathrm{L}_{\mathrm{x} 6}$ Product Quality $+\mathrm{e}_{10}$

Product specifications were descriptions of the products produced by the following peer under the manufacturers' plans. In this research, product specifications consisted of product prices and production codes. Pricing of products had gone through various stages and by conducting a market review to follow consumers' and producers' expectations. Apart from price, the production code was also included in product specifications. This production code consisted of the date the rice produced and no longer suitable for consumption. The production code was usually given according to the planning carried out by the company. The planning could be related to the production schedule of rice by the producer.

Apart from product specifications, another factor formed was product quality. According to Kotler \& Amstrong (2008), the definition of product quality is a set of characteristic features of goods and services that can meet needs, which is an understanding of a combination of durability, reliability, accuracy, ease of maintenance, and other attributes of a product.

Product quality needed the immediate attention of companies/ producers, considering that a product's quality was closely related to consumer satisfaction, which was the goal of marketing activities carried out by producers.

It is important to note that the quality of the product was not reviewed by the company standpoint, it was seen from the perspective of the customer (Razak et al., 2016). In this study, the label's attributes integrated into product quality consisted of organic certification labeling, net weight, nutritional content,

Table 5. Results of Factor Analysis on Rice Product Labels

\begin{tabular}{lcclr}
\hline Factor Name & Eigenvalue & Variance (\%) & Origin Variable & Factor Loading \\
\hline \multirow{2}{*}{ Product Specification } & \multirow{2}{*}{3.132} & \multirow{2}{*}{44.750} & Price & 0.790 \\
& & & Production Code & 0.794 \\
\hline \multirow{3}{*}{ Product Quality } & \multirow{3}{*}{1.152} & \multirow{2}{*}{16.463} & Organic Labelling & 0.749 \\
& & & Net Weight & 0.599 \\
& & & Nutrional Info & 0.701 \\
& & BPOM & 0.845 \\
& & SNI & 0.820 \\
\hline
\end{tabular}


$\mathrm{BPOM}$ registration number, and SNI label. This attribute indicates the quality of the rice product being traded. The inclusion of an organic certification label shows that the product has been registered in organic certification to improve its quality. The net weight and nutritional content illustrate that the rice product being sold is a product that considers the product's quantity, which can be justified later. The inclusion of nutritional content on the label can assure consumers that the rice product they buy has the appropriate content to make a high-quality product. The BPOM registration number and SNI label state that rice products have gone through a particular series of processes to obtain the label so that consumers will think that the labels can indicate the quality of the product. According to Kotler (2002), if a product can carry out its functions, it can be a good quality product. If the attributes on the label inscribed on the product's quality can be proven according to what is said on the packaging, then the rice product is said to be of good quality.

\section{CONCLUSION AND SUGGESTION}

Two factors were considered in making rice product purchasing decisions, namely product specifications, and product quality. Product specifications consisted of price and production code, while product quality consisted of organic labeling, net weight, nutritional information, BPOM labels, and SNI labels. Most of the respondents (67.16\%) who made decisions about labeled rice products read the labels on rice products before buying the labeled rice products.

Based on the research results, the number of respondents paying attention to rice product labels was greater than those who did not. It can be considered by producers to make a good packaging plan to follow what consumers expect. Besides, the price of labelled rice, which tends to be higher than unlabelled rice, could be an option for producers who previously sold unlabelled rice to provide attractive labels and packaging to increase rice products' selling value.

\section{REFERENCES}

Abigail, O., Schewmake., S., Tabrew, L., \& Vandenberg, M. (2012). Carbon Labelling for Consumer Good Foods. https://econpapers.repec.org/ paper/agsaaea12/124369.htm

Aygen, F. G. (2012). Determinants of Nutrition Label Use among Turkish Consumers. International Journal of Humanities and Social Science, 2(7), 53-70.

Badan Pusat Statistik. (2019). Provinsi DI Yogyakarta dalam Angka. 
Bandara, B. E. S., De Silva, D. A. M., Maduwanthi, B. C. H., \& Warunasinghe, W. A. A. I. (2016). Impact of Food Labeling Information on Consumer Purchasing Decision: With Special Reference to Faculty of Agricultural Sciences. Procedia Food Science, 6(Icsusl 2015), 309313. https://doi.org/10.1016/j. profoo.2016.02.061

Campos, S., Doxey, J., \& Hammond, D. (2011). Nutrition Labels on Pre-Packaged Foods: A Systematic Review. Public Health Nutrition, 14(8), 14961506. https://doi.org/10.1017/ S1368980010003290

Daud, N. M., Ramli, L., Jemahadi, N., \& Razalli, R. H. (2011). Examining Critical Success Factors of Consumers' Attitude Towards Nutritional Labelling of Smes Products in Malaysia. Australian Journal of Basic and Applied Sciences, 5(8), 944-950.

Escandon-Barbosa, D., \& Rialp-Criado, J. (2019). The Impact of The Content of The Label on The Buying Intention of A Wine Consumer. Frontiers in Psychology, 9(JAN), 1-11. https://doi.org/10.3389/ fpsyg.2018.02761
Hodgkins, C., Barnett, J., WasowiczKirylo, G., Stysko-Kunkowska, M., Gulcan, Y., Kustepeli, Y., Akgungor, S., Chryssochoidis, G., FernándezCelemin, L., Storcksdieck Genannt Bonsmann, S., Gibbs, M., \& Raats, M. (2012). Understanding How Consumers Categorise Nutritional Labels: A Consumer Derived Typology for Front-of-Pack Nutrition Labelling. Appetite, 59(3), 806-817. https://doi. org/10.1016/j.appet.2012.08.014

Kotler, P. (2002). Manajemen Pemasaran Edisi Millenium Jilid 2. PT Prenhallindo.

Kotler, P., \& Amstrong, G. (2008). Prinsipprinsip Pemasaran Jilid 1. Erlangga.

Kumar, N., \& Kapoor, S. (2017). Do Labels Influence Purchase Decisions of Food Products? Study of Young Consumers of An Emerging Market. British Food Journal, 119(2), 218229. https://doi.org/10.1108/ BFJ-06-2016-0249

Lagerkvist, C. J. (2013). Consumer Preferences for Food Labelling Attributes: Comparing Direct Ranking and Best-Worst Scaling for Measurement of Attribute Importance, Preference Intensity and Attribute Dominance. Food 
Quality and Preference, 29(2), 77-88. https://doi.org/10.1016/j. foodqual.2013.02.005

Liao, L., Luo, L., \& Tang, Q. (2015). Gender Diversity, Board Independence, Environmental Committee and Greenhouse Gas Disclosure. British Accounting Review, 47(4), 409424. https://doi.org/10.1016/j. bar.2014.01.002

Lloret, S., Ferreres, A., \& Tomás, A. H. e. I. (2017). The Exploratory Factor Analysis of Items: Guided Analysis Based on Empirical Data and Software. Anales de Psicología / Annals of Psychology, 33(2), 417432. https://doi.org/10.6018/ analesps.33.2.270211

Prudon, P. (2015). Confirmatory Factor Analysis as a Tool in Research Using Questionnaires: A Critique,. Comprehensive Psychology, 4, 03.CP.4.10. https://doi. org/10.2466/03.cp.4.10

Razak, I., Nirwanto, N., \& Triatmanto, B. (2016). The Impact of Product
Quality and Price on Customer Satisfaction with the Mediator of Customer Value. Journal of Marketing and Consumer Research, 30(2012), 59-68.

Van Boxstael, S., Devlieghere, F., Berkvens, D., Vermeulen, A., \& Uyttendaele, M. (2014). Understanding and Attitude Regarding The Shelf Life Labels and Dates on PrePacked Food Products by Belgian Consumers. Food Control, 37(1), 85-92. https://doi.org/10.1016/j. foodcont.2013.08.043

Vecchio, R.,\&Annunziata, A.(2012).Italian Consumer Awareness of Layer Hens' Welfare Standards: A Cluster Analysis. International Journal of Consumer Studies, 36(6), 647-655. https://doi.org/10.1111/j.14706431.2011.01040.x

Wade, S., \& Kennedy, O. B. (2010). Does Gym Use Impact Upon Nutritional Knowledge? British Food Journal, 112(1), 44-54. https://doi.org/ 10.1108/00070701011011191 